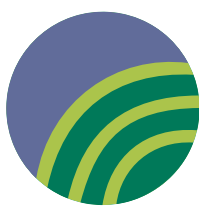

\title{
Katie Van Aken
}

\section{Materials scientist, budding entrepreneur, and outreach enthusiast}

\section{By Humaira Taz}

$\mathrm{K}$ atie Van Aken has always been interested in outreach programs for children, but she said it peaked during her $\mathrm{PhD}$ years. "Being in the lab all the time can be a little bit monotonous and boring. In contrast, outreach activities are very rewarding when you see all the kids getting excited about science."

Although Katie completed her $\mathrm{PhD}$ degree in materials science from Drexel University, with a research focus on materials for energy storage, she did not pursue the traditional route of staying in academia. She is currently working as the lead engineer at Dragon Spectral, a startup company out of the Electrical Engineering Department at Drexel. They are trying to develop and commercialize their technology — an optical filter for imaging devices. "This work is very different from my $\mathrm{PhD}$. Most of the time, I am creating demos for potential investors and customers. There is research involved, but it is not for publication purposes. Rather we are trying to develop a product for the market," explained Katie. She added that eventually she would love to start her own company, so in that regard, this position is allowing her to learn the basics of entrepreneurship.

During her time as a doctoral student, Katie did not follow the stereotypical lifestyle of a graduate student. While the majority of graduate students spend their days, nights, and weekends at the lab, Katie involved herself in several outreach and leadership activities at Drexel and beyond. As the president of the Materials

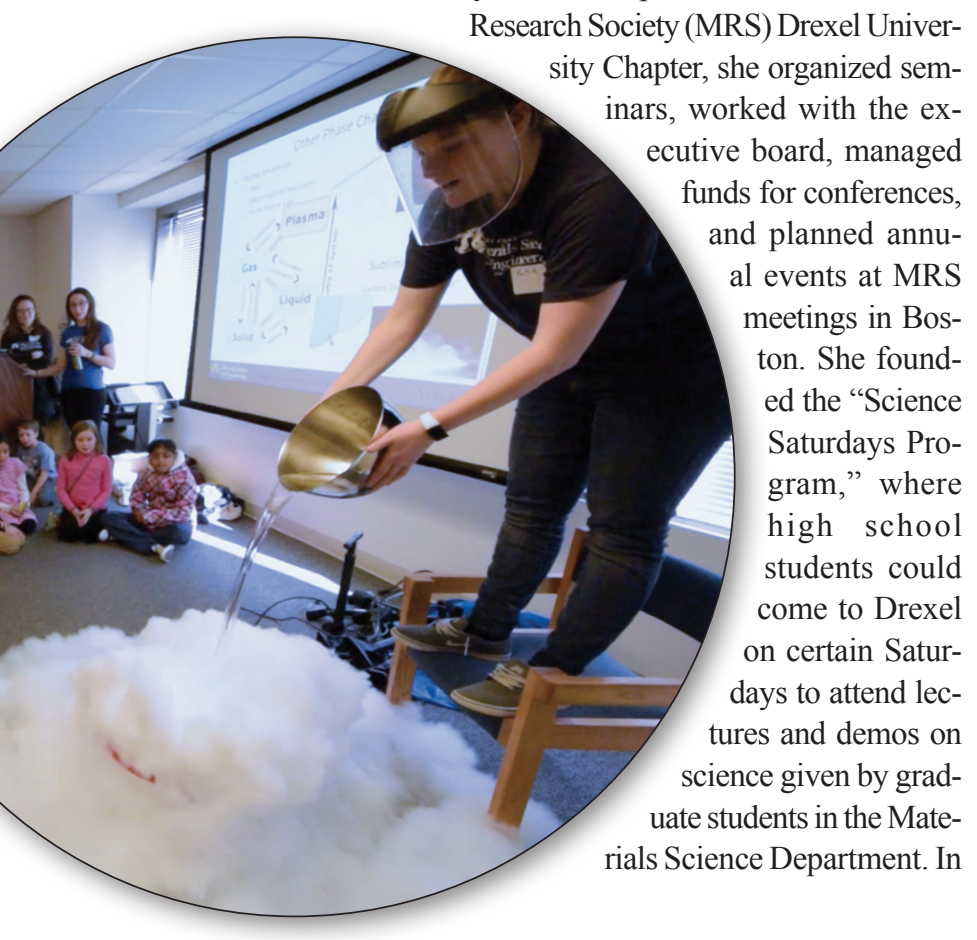

addition, she was a math and science tutor for local high schools, and she participated as a judge in research competitions and science fairs held at Drexel University and local high schools.

Her favorite activity, however, has been Philly Materials Day where she was a special demonstration leader.

"This is an all-day event sponsored by the National Science Foundation and devoted to materials science. It's open to kids of all ages, and there are usually panelists and demos on various materials-related topics. Each year, this event draws more than 2000 people," explained Katie. The event also has some hands-on workshops for kids to learn about scientific concepts. One of the big hits was a demo she did where she created a cloud as big as a room. "Kids loved it! You could see them taking out their phones to Snapchat. The best part was the excitement on their faces when you explained the phenomenon to them." Katie also mentioned that she loved talking to the parents. "Parents come to these events to accompany their kids, but they end up learning new things too. It's a very rewarding feeling when they realize oh, so this is how a TV screen works!"

Katie's experience with outreach events has come in handy in her current position at the startup. "It teaches you to explain concepts in a simple manner, and that in turn helps your customers and potential investors understand the product better." Another manifestation of her explanation skills occurred during the MRS Hackathon, a programming event targeted toward the materials genome project hosted by MRS. Participants were given 24 hours to develop 30-second pitches of their ideas for materialsrelated software, form teams around those ideas, and bring those concepts to life with working code. "I don't know the first thing about coding, but I went up there, pitched my idea to a complete group of strangers, and actually managed to get a team together to work on my idea. It was a fun experience!"

She ended by saying that outreach events are an important learning experience for her as well. When kids get excited about science, they throw out crazy ideas. "You never know, we might get inspired by one of those ideas someday, and it could lead to a revolutionary technology." 


\title{
Become an MRS Gongressional
} Science and Engineering Fellow!

\author{
Help improve the interface \\ between science and \\ legislative decision making.
}

\section{Advocate for policies} that will facilitate the discoveries of the future.

\section{Play a crucial role as you educate the public about the benefits of science.}
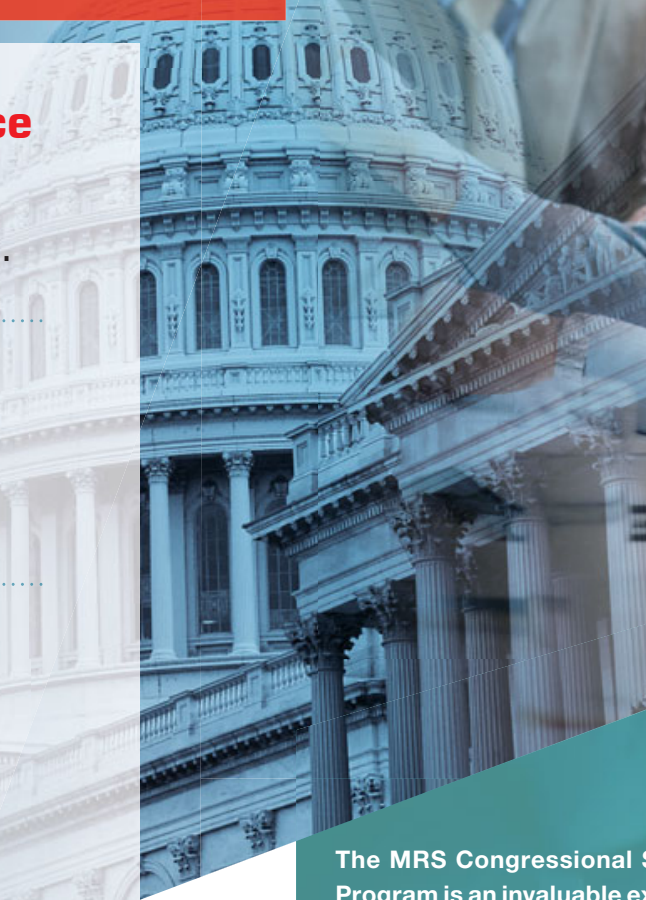

The MRS Congressional Science and Engineering Fellowship Program is an invaluable experience, but don't just take our word for it. Our past Congressional Fellows explain it best!

"Academia taught me how to think, but the MRS Congressional Fellowship taught me how to get things done. Never have I had such leverage, such opportunities to comingle with dignitaries, to structure agreements and broker deals, as I did in that year. I learned

Decisions made by Congress, regulatory agencies and local government have profound effects on the way in which science is conducted. By keeping decision makers well informed on the current affairs of the scientific community, MRS Congressional Science and Engineering Fellows ensure the right choices are being made. Now's your time to make a difference!

The Materials Research Society offers materials scientists two exciting opportunities to participate in, and contribute to, the federal policymaking process, while learning firsthand about the intersection of science and policy.

During your year as a Fellow you will:

- contribute widely to the effective use of materials science knowledge in government

- broaden awareness about the value of scientist- and engineer-government interaction among society members and within government

- have significant freedom to follow specific topics and issues that interest you how to navigate past armies of secretaries shielding a VIP, enlist military support for a project, take a rough idea and make it law, to fashion an event into a sound bite and then watch it propagate across the news. I learned to take data and present it in such a way that it gravitated, almost of its own accord, all the way up to the Vice President of the United States. These are skills anyone, who is going anywhere, can use."

Merrilea Mayo Founder, Mayo Enterprises, LLC.

MRS Congressional Fellow 1998-1999 Office of Senator Lieberman

"At the end of the fellowship year I found that I was enjoying 'doing' science policy more than just teaching about it, and I ended up staying on in Rep. Honda's office as a member of the staff where I have remained for over a decade. I would not have had that opportunity without the Congressional Fellowship. I encourage anyone who wonders about how federal policies are developed or wants to have a greater role in that process to apply to be a Congressional Fellow."

Eric Werwa Legislative Director, Congressman Mike Honda

MRS Congressional Fellow 2001-2002 Office of Congressman Mike Honda

To learn more about the MRS Congressional Science and Engineering Fellowship Program and how you can apply, visit www.mrs.org/congressional-fellows.

Applications for the MRS/OSA Fellowship must be postmarked or emailed by 11:59 pm (ET), Friday, January 5, 2018.

Applications for the MRS/TMS Fellowship must be submitted through the MRS Awards Nomination

Submission Portal (https://awards.mrs.org) and must be received by 11:59 pm (ET), Friday, January 5, 2018. 


\section{The Materials Research Society and Cambridge University Press}
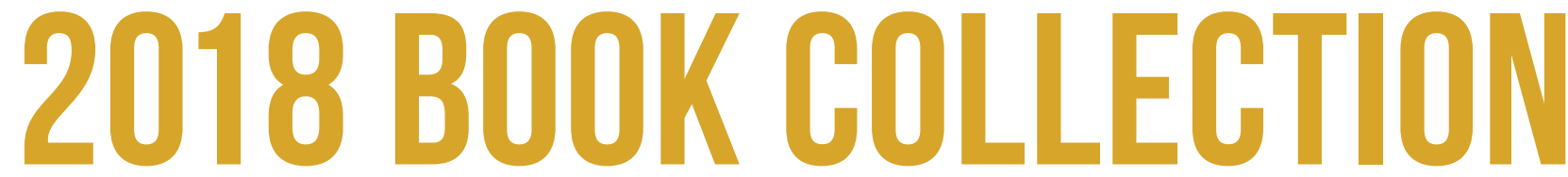
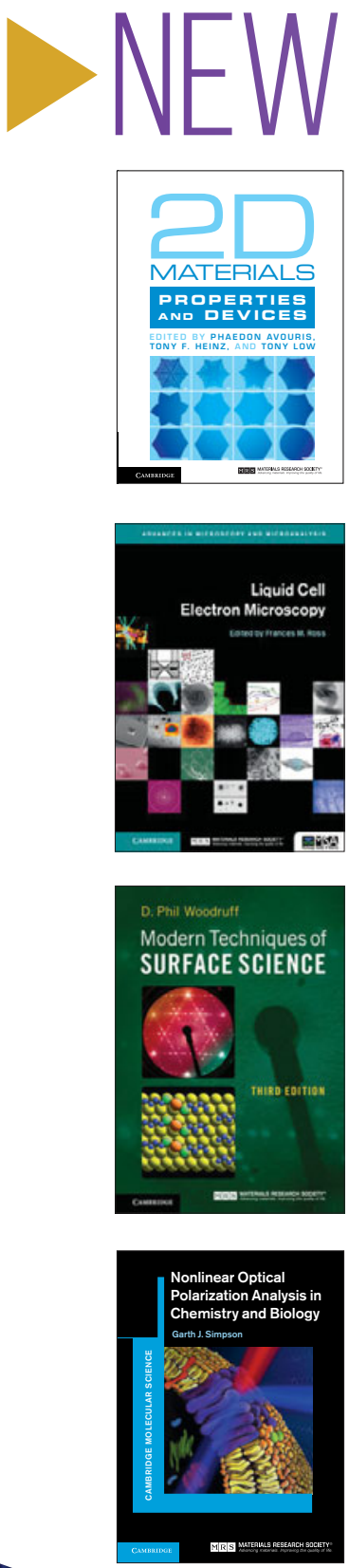

Nonlinear Optical Polarization Analysis in Chemistry and Biology AUTHOR: Garth J. Simpson

ISBN: 9780521519083

List Price: $\$ 175.00$

MRS Member Price: $\$ 140.00$

List Price: $\$ 175.00$

MRS Member Price: $\$ 140.00$ Third Edition

AUTHOR: D. Phil Woodruf

AUTH: 0781107023109

MRS Member Price: $\$ 100.00$

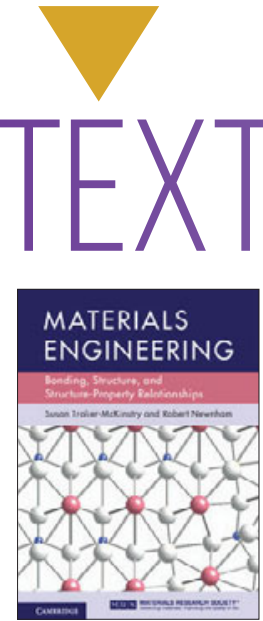

Modern Techniques of Surface Science
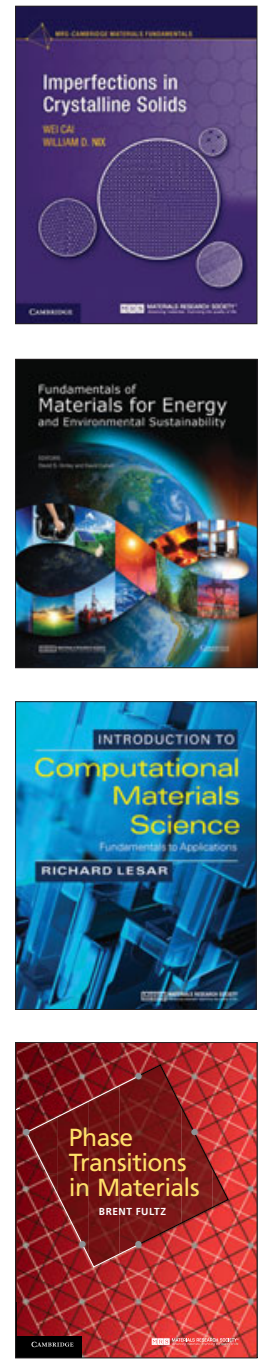

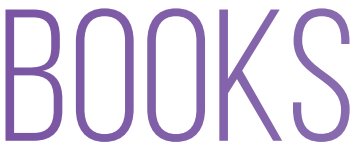

\section{NEW TEXTBOOK}

Materials Engineering-

Bonding, Structure, and Structure-Property

Relationships

AUTHORS: Susan Trolier-McKinstry and Robert E. Newnham ISBN: 9781107103788

List Price: $\$ 95.00$

MRS Member Price: $\$ 76.00$

Imperfections in Crystalline Solids First Textbook in the New MRS-Cambridge Materials Fundamentals Series

AUTHORS: Wei Cai and William D. Nix ISBN: 9781107123137

List Price: $\$ 65.00$

MRS Member Price: $\$ 52.00$

Fundamentals of Materials for Energy and Environmental Sustainability

EDITORS: David S. Ginley

and David Cahen

ISBN: 9781107000230

List Price: $\$ 113.00$

MRS Member Price: $\$ 90.00$

Introduction to Computational Materials Science Fundamentals to Applications

AUTHOR: Richard LeSar

ISBN: 9780521845878

List Price: $\$ 100.00$

MRS Member Price: $\$ 80.00$

Phase Transitions in Materials

AUTHOR: Brent Fultz

ISBN: 9781107067240

List Price: $\$ 108.00$

MRS Member Price: $\$ 86.00$

To view the entire collection, visit www.cambridge.org/mrs-cambridge 